New Zealand journal of industrial relations, 1991, 16, 109-125

\title{
Legal change and labour market restructuring in Western Europe and the US
}

\author{
Simon Deakin*
}

The major changes that have taken place in the New Zealand labour market since 1984 , and which are reflected in recent changes to the welfare system, are not unique and follow trends that have developed in other OECD countries in the last decade. One of the most significant of these trends is legislative and other moves to encourage greater "efficiency" in the labour market. Deregulation, involving the withdrawal of legal guarantees of employment protection and union organization, is only one of the techniques which governments have used in an attempt to promote labour market flexibility over the past decade. In continental Europe new forms of employment and the flexibilization of working time have been encouraged without dismantling the framework of employment rights. In many cases this has involved an extended role for collective bargaining and worker representation at plant and company level. In the US and Britain, by contrast, flexibility has been pursued at the cost of destabilizing the employment relationship, undermining training and job quality.

\section{Introduction}

The New Zealand Employment Contracts Act 1991 aims to develop a "more efficient labour market" through a series of deregulatory measures. The ending of the award system and the restraints placed upon collective bargaining seem likely to lead to a greater role for firm-level wage determination and individual contracting at the expense of marketwide labour standards. This paper examines the international experience of attempts to use changes in labour law as a means of enhancing labour market flexibility, with particular reference to the US and Western Europe. The flexibility debate has affected all the countries examined here, but there has been no general adoption of deregulation. In the case of the traditionally "voluntarist" industrial relations systems of the US and Britain, the emphasis has indeed been on confining the role of collective bargaining as a means of regulating terms and conditions of employment, and on reducing employers' costs through cuts in employment protection and in the social wage. On the other hand, in the systems of continental Europe, the legal "floor" of minimum rights has been maintained alongside new forms of legal intervention designed to promote a greater variety of contractual forms of employment, including part time and temporary work and a more flexible working week for full timers (Deakin, 1990b). In all systems there is evidence of considerable institutional change but as yet no clear solution to the problems which policies of flexibilization were meant to address, namely the need to tackle high unemployment and to accommodate new developments in firm organization, technology and worker mobility. 


\section{The flexibility debate: legal and policy perspectives}

In the early stages of the flexibility debate, the traditional forms of labour law regulation were presented more or less uniformly as potential "barriers" or "rigidities" to the efficient operation of the labour market (UK Department of Employment, 1985; OECD, 1986a). A distinction was drawn between micro- and macro-level flexibility. At the micro-level, the model of the "flexible firm" developed by the Institute of Manpower Studies proved to be influential (Atkinson, 1985). This identified functional, numerical and financial flexibility as the main dimensions of firms' flexible strategies of labour management. This could be put slightly differently in terms of flexibility of labour inputs, on the one hand, and flexibility of costs, on the other. In general terms, functional flexibility assumed the allocation of a greater range of internal tasks to employees, numerical flexibility involved variations in the numbers and in the type of workers employed by the firm and financial flexibility greater variation in wage and other payments. In each case the intention of flexibility strategies was to enable firms to adjust as quickly as possible to external uncertainties.

In theory, at any rate, legal constraints imposed fixed costs and long-term commitments upon firms which discouraged this kind of flexibility. Laws and collective agreements setting minimum terms and conditions and protecting security of employment could be seen as restricting firms' ability to hire and fire, set variable wage rates, move workers around between tasks, vary production levels by modulations in working time and to employ sub-contract or part time labour. The need for legal changes which was only implicit, at best, in the Institute of Manpower Studies model, became an active premise of labour market policy in Britain (UK Department of Employment, 1985, 1986, 1988).

At a macro-level, the need for greater flexibility was put in terms of the more effective response of wages to changes in labour demand between sectors and in the economy as a whole, and in terms of the greater adaptability and mobility of workers (Metcalf, 1986). At a time of high unemployment and reduced labour demand within national economies, the downwards movement of wages was said to be needed to restore equilibrium in the labour market, while economic restructuring required greater willingness on the part of workers to move to sectors which were expanding. From this point of view, collective bargaining at national or industry level might act artificially to compress wage differentials, so pushing up unemployment and slowing down the process of the redeployment of labour. Fixed employment protection and social security costs, which employers could bear with equanimity at a time of prolonged economic growth and high levels of employment, would also, in a period of recession, depress labour demand and discourage the hiring of new recruits:

In this respect the economic consequences of employment protection regulations are similar to unemployment benefits. When the economy is functioning at high activity rates, high levels of employment and social security seem entirely bearable for the economy. However, these features of the system also make the economy vulnerable to a prolonged down-turn. Employment protection costs rise in the same way as the social security bill rises. Both further dampen the demand for labour in a vicious circle movement (Emerson, 1988, p.781).

It followed that even if wholesale deregulation was impractical and undesirable given the disruption it would cause to existing employment relationships, a form of partial deregulation based on legal dualism would help to increase labour market participation rates and encourage the hiring of new recruits by firms. "Dualism" in this sense refers to a strategy of relaxing job protection rules and the social costs of hiring for new employees while leaving the acquired rights of "existing job holders" intact. A condition 
of such a strategy, however, was said to be the maintenance of minimum wage laws and an extensive social security system to protect those groups left without significant job security (Emerson, 1988).

The notion that over-rigid systems of labour law and industrial relations formed one of the main causes of high unemployment in Western Europe in the 1980s was popularized in the Dahrendorf report to the OECD (OECD, 1986b). This suggested that the Western European economies possessed neither the "external" or market-level mobility of the US, nor the internal or firm-based mobility of the Japanese system. Empirical support for this observation proved elusive (Metcalf, 1986), but it became influential in policy-making circles as an explanation of "Eurosclerosis". Higher levels of job mobility and of job creation in the US were favourably compared with the extended job tenure and poor job creation record of the European systems, with the implication that the American record of sustained employment growth was a superior means of providing fundamental job security (Addison, 1986).

In general, 3 main legal techniques for the promotion of labour market flexibility can be identified. First, there has been a partial withdrawal of the State from the process of setting basic labour standards, a move aimed at encouraging new hirings and, in particular, the growth of non-standard forms of employment (part time, temporary work, self-employment). Cuts in social protection have also been used to encourage the unemployed back to work. As anticipated, the result has been to create varieties of legal dualism in the treatment of new labour market entrants as against existing job holders. Second, the State has actively subsidized employers' hiring costs by a number of means ranging from direct payments to tax and social security rebates. This has also involved the encouragement of non-standard employment forms. Finally, governments have sought to induce a greater degree of decentralization in the collective bargaining system, promoting company- and plant-level agreements as a means of restoring autonomy and flexibility to firms in their wage and labour management strategies.

Within this general picture, however, there exist not only very considerable differences between countries in the degree and scope of legal changes, but also differences in the ways in which so-called deregulation has led to new roles for the State in the labour market. In this regard it is "an elementary error to suppose that the achievement of employment flexibility need entail a decreasing incidence of statutory control of employment rights" (Napier, 1989, p.207; Mückenberger, 1989). In Britain, for example, the withdrawal of employment protection from certain groups of workers is only one aspect of recent legislative changes; the State's attempts to control and restructure collective bargaining have made it necessary to intervene on a far greater scale than before in the regulation of industrial action and union procedures. In the continental European systems, the role of new legislation has been the different one of redefining the relationship between collective labour law and the individual contract of employment, in the process creating new varieties of employment status to accommodate the "atypical" forms of employment (Erbes-Seguin, 1989; Deakin, 1990b).

In order to examine these complex and sometimes contradictory tendencies in the development of the law, and in the role of the State more generally in the labour market, 4 main areas of labour law policy will be outlined in turn: the framework of collective bargaining; the reorganization of working time; job security; and the promotion of atypical work.

\section{Collective bargaining and minimum standards in the labour market}

Different cultures and traditions of collective bargaining have been partly responsible for the separate routes taken towards flexibility and decentralization in wage determination systems. In the US, the legal framework established by the Wagner and Taft-Hartley 
Acts had produced, even prior to the 1980 s, a decentralized and highly uneven system of collective bargaining which lacked, moreover, the support of a comprehensive statutory "floor" to terms and conditions of employment of the kind found in Western Europe (Deakin, 1990b). In some respects, the American system is similar to the regime imposed in New Zealand by the Employment Contracts Act. Nonetheless, and despite the US influence on the drafting of the Employment Contracts Act, the American legislation still encourages collective bargaining by trade unions. Under the American system, employers' legal duty to bargain is normally located at plant or company level and only arises once a union has achieved "sole bargaining agent" status in a workplace vote of the employees. The union then has exclusive rights of representation. Within collective bargaining agreements, issues of discipline and dismissal are dealt with via legally binding arbitration. Outside the unionized sector, on the other hand, employment relationships are governed, at least formally, by the doctrine of employment at will, under which the employer retains general powers to set and to vary the terms of employment and to hire and lay-off at will. There is no job protection legislation at federal level and very little in the states.

Because the law grants a number of privileges to sole bargaining agents, essentially making them monopoly representatives until such time as they are "decertified" by a further workplace ballot, this form of legally supported bargaining has crowded out other forms of collective relationship with employers. Because the legal unit of bargaining is located at the level of the plant or company, sector-level or cross company "pattern" bargaining has been difficult to achieve. This legal structure has been widely criticized as excessively constraining and destructive of union autonomy (Atleson, 1984; Tomlins, 1985; Rogers, 1990). Since the peak after World War II, the numbers in trade unions have been steadily declining; first in relative and then in absolute terms, until in the mid1980s union density fell to less than 20 percent of the industrial labour force. During the 1980s there has been a net depletion in the coverage of collective bargaining agreements, as union losses in decertification elections have increased, and a further decline in pattern bargaining (Rosenberg, 1989a).

More recent changes in the law during this period have hastened the decline in the coverage of collective agreements. Decisions of the courts, and of the National Labor Relations Board, have restricted the employer's duty to bargain in a number of cases, most notably over the relocation of plant and resources to new sites, the resort to subcontract and temporary labour in an effort to avoid the coverage of collective agreements, and even, in some cases, the imposition of unilateral changes in terms and conditions of employment (Atleson, 1984; Clark, 1986; Rosenberg, 1991). Bankruptcy proceedings and other devices from company and insolvency law have also been used to escape the effect of otherwise binding collective agreements (Weiler, 1989). Another development has been the growth in a number of industries of concession bargaining, involving real wage cuts and the loss of holiday entitlements as part of a package of job preservation and the introduction of lower wage rates and inferior benefits for new recruits, so creating a dual employment structure within the employment unit (Rosenberg, 1989a).

The possibility of relocating plant in non-union environments in the south and west of the country has had a considerable impact on the general undermining of social and labour standards. This process has spread beyond collective agreements to cover more general aspects of the social wage, with states and cities competing to offer a "good business climate" of low wages and tax concessions. In this respect:

the regulations that industry complains about most loudly and most often are those that intervene in the workplace relationship between labor and management - laws having to do with minimum wages, affirmative action, and health and safety - and state laws that provide for some form of income maintenance: unemployment insurance and food stamps for those who usually 
work, and welfare for those who often do not (Bluestone and Harrison, 1982, p.185; Harrison and Bluestone, 1988).

Attempts by states to introduce effective social controls over the mobility of capital are limited by the constitutional doctrine which reserves powers over inter-state commerce to the federal Congress, and then imposes limits on their use to generate binding social standards. This system has kept federal labour standards low, and encouraged states to engage in the "destructive competition" of offering short-term benefits to attract companies (Tarullo, 1989). Between 1977 and 1990 there was no increase in the nominal value of the federal minimum wage which remained throughout at $\$ 3.35$ per hour, with only 10 states setting minimum rates above this level. In 1990, legislation passed with the agreement of the Bush administration raised the nominal value of the federal minimum, while at the same time introducing a reduced rate for young workers (Rosenberg, 1991).

Britain is similar to the US in having a weak and partial floor of rights in employment legislation and a preference for voluntarism, but it differs in that the collective bargaining structure has grown up for the most part outside the scope of direct legal controls (Wedderburn, 1986). Accordingly legal reforms in the 1980 s have not sought to regulate directly the collective bargaining process as such, but rather have taken the form of "restrictive" legislation limiting the economic power of unions by narrowing the right to strike, preventing enforcement of the closed shop, imposing rigid procedural requirements upon unions taking industrial action, and giving employers greater leeway to victimize and discipline strikers (Auerbach, 1991).

Although collective agreements in some form still nominally cover around twothirds of employees in Britain, there has been a steady movement since the $1970 \mathrm{~s}$ in favour of plant and company level bargaining and a loss of effectiveness of sector-level standards in regulating occupational labour markets (Brown and Walsh, 1990). The reforms to strike law have contributed to this demise of sector-level collective bargaining by limiting strike action to issues arising within a single employment unit or workplace and ruling out most forms of secondary action. The need to conduct industrial action on a company-by-company basis contributed to the breakdown of the national engineering agreement in 1989-90, as several larger firms reached separate agreements with the engineering unions, outside the national structure, over the reduction of working hours.

Sector-level collective bargaining has also been undermined by the abolition, in the early 1980s, of fair wages legislation which made provision for the compulsory extension of minimum terms in collective agreements to employers who did not recognize trade unions. The limited, and not entirely successful, recognition laws which operated in the 1970 s were also abolished at this time. These legal changes have greatly facilitated the government programme of privatizing large parts of the public sector and requiring local government and health authorities to put services out to contract, whereupon they now become legally free from the application of minimum rates laid down in pre-existing collective agreements. In many cases, the profits of contract firms have been derived wholly or mainly from the downgrading of terms and conditions of employment which this process makes possible (Ascher, 1987). A certain amount of wage flexibility has therefore been introduced in sectors which include construction, contract cleaning and other ancillary services. However the growth of firms whose profits depend so heavily on cheap labour strategies has had adverse consequences for productive efficiency and the quality of service (Evans, 1990; Deakin and Wilkinson, 1991). Within the remaining areas of public sector employment, regional and localized pay bargaining has been encouraged by measures which include the devolution of commercial decision-making to individual schools and hospitals, which now have the possibility of opting out of local government control altogether (Fredman and Morris, 1989).

State regulation has also been withdrawn in the few areas where direct support for collective bargaining used to exist. In the absence of a minimum wage, basic terms and 
conditions are given legal effect in certain low-paying sectors through the wages councils, which currently cover around 10 percent of the employed labour force. Whereas the wages councils used to operate as a substitute for sector-level collective bargaining by setting a series of rates for various grades of workers, after the Wages Act 1986 they are restricted to setting single minimum wage rates for all workers in their respective sectors. The 1986 Act also abolished the power to establish new bargaining machinery outside the traditional sectors of low pay, and removed workers under the age of 21 from the scope of the remaining protections.

In Britain and the US, the removal of effective collective bargaining from large parts of the labour market leaves a void in terms of the social regulation of terms and conditions, with only the social security system setting any minimum floor to household incomes. In most of the systems of continental Europe, by contrast, minimum statutory employment standards have historically played a more significant role in underpinning the collective bargaining system, a role which has been maintained despite the increased priority given to flexibilization in recent years. In these systems a general floor of rights in hours and wages extends to all areas of the labour market either through universal legislation or through legally-enforceable collective agreements (Deakin, 1990b). Against this background of a comprehensive floor of rights, 2 main techniques have been used to enhance flexibility through collective bargaining: the promotion of plant and company level bargaining to implement limited derogations from general standards; and the involvement of unions and employers' associations with government in the adoption of new "negotiated laws" on the substantive questions of flexibility (Lyon-Caen and Mariucci, 1987; Wedderburn and Sciarra, 1988).

The use of legislative "remittals" to collective bargaining marks a break from the previously strict insistence in the civil law systems on the principle of "non-derogability" - in other words, the principle that collective agreements may improve on, but may not go below, the minimum rights conferred by social legislation (Kravaritou-Manitakis, 1988, Erbes-Seguin, 1989). Examples of remittals in the field of working time and atypical work include the West German Employment Promotion Act (Däubler and Le Friant, 1986), the French legislation of 1982 and 1987 on the organization of the working week, and Italian legislation of 1984 on part time and training contracts, and of 1987 on fixed-term contracts. "Solidarity contracts" in the French and Italian systems, which are intended to facilitate general reductions in working time and in salary in return for job guarantees and a commitment to new hirings from the employer, also illustrate the point. In each case, the:

new role of collective agreements [which] has emerged is that of "flexibilisation" of the employment contract and, in particular, that of working time, which is an important part of the exchange, stemming from the effects of the economic crisis, between employment and restrictions in wages (Wedderburn and Sciarra, 1988).

Elsewhere this technique has been referred to as "bargained deregulation" (Wedderburn, 1990, p.35).

There are 3 reasons why this form of flexibility is different in its effect to the type of concession bargaining seen in some sectors of the US labour market. First, as already noted, collective bargaining in the European systems takes place within the context provided by the floor of rights, which will apply in the absence of any agreement on flexibility. In the US and to some extent in Britain, by contrast, the only floor under collective bargaining is that provided by the social security system. Secondly, flexibility bargaining in Western Europe has attempted to avoid the 2-tier employment structure which has characterized concession bargaining in the US, with new entrants employed on markedly inferior wages and conditions of work. Concessions or "derogations" agreed by the unions may affect all employees, and not just new entrants, as in the case of the 
French and Italian "solidarity contracts" in which a general reduction in working time and salaries is agreed in exchange for the hiring of new recruits and a partial State subsidy to compensate for the lost wages. Where outsiders are hired on a temporary or part time basis as a result of special derogations, legislation in France and West Germany makes specific provision for these workers to be integrated into collective agreements and to receive rights on a par with full time workers (Deakin, 1990b). Third, the Western European style of legislation lays down certain procedural safeguards for the conclusion of flexibility agreements which are entirely lacking in the American context, notably the requirement that flexibility agreements must be concluded by unions which have "most representative" status at plant or enterprise level (Wedderburn and Sciarra, 1988). Unlike the American bargaining representatives, these unions do not hold monopoly representation rights.

The tendency towards "negotiated laws" is another feature of attempts to implement labour market flexibility in the European systems in the 1980s. In Belgium, legislation of 1987 on the introduction of flexible working time arrangements at company level was preceded by the conclusion of a national level agreement between government, unions and employers the year before. In France, similar legislation of 1987 aimed at liberalizing the regulations concerning the working week was based on a national agreement in the engineering industry. In 1989, an agreement on the reorganization of working time was concluded between the 2 principal national employers' associations and 2 out of the 4 main national trade union confederations. Even instances of clear deregulation have been a prelude to national level negotiations between governments and the 2 sides of industry, as in the case of the removal, in 1986 in France, of the long-standing requirement for the administrative approval of redundancies.

\section{The reorganization of working time}

The introduction of more variable working schedules in firms - moving away from the standard working day and week in favour of variable shifts, weekend working and annualized hours - is seen as an important aspect of internal "functional" flexibility. This is said to benefit the firm by providing it with a greater capacity to meet fluctuations in demand, and also to benefit individual workers by offering a greater variety of working arrangements and choices. In many of the continental European systems, the traditional forms of regulation of the working week - whether through law or collective bargaining apparently posed an obstacle to such company strategies. In Britain and the US, on the other hand, such legal constraints on the formation of new working arrangements did not exist. However, the absence of a relatively rigid legal framework for working time in these systems has long allowed other forms of "flexibility" which may have obviated the need for some of the more creative arrangements envisaged in the flexibility debate: namely, the possibility of extensive overtime and, in some sectors, very long basic hours.

In the US, the Fair Labor Standards Act of 1938 requires the payment of premium overtime rates of time and a half for weekly hours worked above the 40 hour figure and regulates the hours of young workers. There are a number of similar laws at state level. There is no attempt to use the law to set a maximum working week as such. Within the unionized sector, hours are set by collective agreements. Average working hours in the US for full time workers have not changed much in the past 20 years, at around 43 hours, roughly the same as New Zealand. A slight reduction in average annual working hours in the 1970s, brought about by increased annual leave, was reversed in the 1980s. Paid holidays are on the whole much shorter than in Europe or even New Zealand: the average for the workforce was only 10 days per year in 1986. Service-based increments are used to raise this to an average of 16 days after 10 years employment and 21 days after 20 years. Some trends towards the introduction of flexible working have been reported, 
particularly for the public sector, but they affect only a small proportion of firms and generally take the form of "external" measures of flexibility such as the employment of temporary workers, on-call workers and contract labour rather than wholesale changes to the standard working week for regular employees. More extensive use is made of shift working, nightwork and weekend work (Rosenberg, 1989b).

Within Western Europe, Britain is the only country which does not have effective, general regulation of the length and organization of the working week (Blanpain, 1988). Legislation restricting nightwork by women and young people (over the school leaving age) was repealed in 1986 and 1989 respectively (Deakin, 1990a). Whereas almost every other system has legislation laying down daily and weekly working hours, annual paid leave and restrictions on weekend and holiday working, in Britain this type of regulation has been left up to national level collective agreements, which by the middle of the 1980s had set a general 39 hour basic working week for manual workers in industry. These agreements do not, on the whole, attempt to regulate overtime as such or weekend and shift working, beyond setting minimum premium rates for these hours.

One result of this is that British employers, particularly in manufacturing, rely heavily on overtime and shift work by male manual workers to meet fluctuations in demand; while the employees, in turn, regard overtime earnings as a vital supplement to low basic rates of pay. This has given the debate about the reduction of working time a quite different focus to the situation elsewhere in Europe. Average basic hours worked by manual male employees in Britain fell only slightly from 39.9 in 1980 to 39.1 in 1988 . Once overtime hours are taken into account, however, the average hours of manual male employees rose in the middle 1980s, to reach an average of 45 hours per week for all employees in 1988. The average for those actually working overtime was 55 hours in 1988 and over half of male manual employees worked overtime hours on a regular basis. Some groups worked very long weekly hours with a 60 hour week, including overtime, in some transport sectors (TUC, 1988). There is, by contrast, relatively little evidence of new forms of flexible working such as the annualization of hours and the replacement of overtime by variable shift working; an official survey (ACAS, 1987) found only a small number of company agreements implementing such radical changes. The 1989 dispute over working hours in the engineering industry followed the unions' rejection of a tradeoff between hours reductions and the introduction of flexible shift working at plant level; in the event, a reduction in the basic hours of manual workers from 39 to 37.5 hours was agreed by a number of separate companies, without any move towards the more radical forms of working time arrangement which might have seen the phasing out of overtime.

In contrast, the erosion of the standard working week for industrial workers has proceeded the furthest in those countries where the introduction of new legislation was necessary in order to speed up the process of working time reduction and flexibilization. This has been the case in France where one of the major reforms of the 1982 Auroux laws was the introduction of a general 39 hour basic working week. The law made provision for the implementation of the new standards through collective bargaining at company level, where a legal duty to bargain was also created for the first time, and allowed for limited derogations from the basic norm so long as the 39 hour average was retained throughout the working year. Local bargaining subsequently led to the introduction of company agreements making provision for annualized hours, increased Sunday work and variable overtime, in many cases going beyond what was permitted under the existing law (Erbes-Seguin, 1989). In 1987, a further law was passed which allowed greater scope for flexibility for company agreements and retrospectively validated agreements which had been drawn up in contravention of the earlier legislation. Provision was made for collective agreements at company and sector level to authorize increased overtime working above the high 44 hour threshold for total working hours, Sunday working, and nightwork by women, but with strict safeguards and only if certain conditions based on economic needs of companies were satisfied. 
In West Germany, the engineering workers' strike of 1984 produced reductions in the basic working week first to 38.5 hours and then, in an agreement of 1987, phased reductions to 37 hours from April 1989. Changes to the legal structure of the working week were first put before the Federal Parliament in 1987. At present the Working Time Act of 1938 sets a basic 8 hour day and 48 hour week, with further reductions in the working week and restrictions on overtime taking effect via collective bargaining. The 1987 proposals would allow daily hours to be increased up to 10 and weekly hours to 60 without overtime rates being paid, as long as the 8 hour average is not exceeded over a 4 month period. There would also be exemptions to the current general restrictions on Sunday working and nightworking by women. The West German Trade Union Confederation, the DGB, has opposed the measure and has argued that it will be the first step in a more widespread programme of deregulation designed to open up greater flexibility in wage payments and the internal deployment of labour.

The Belgian legislation of March 1987 is the most far-reaching example of statutory reforms to working time. This followed earlier legislation which led the way to the "Hansenne" working-time experiments and to a national collective agreement in 1986 which formed the basis for the new law. The new legislation permits the basic working day to be extended up to 12 hours. Weekly hours (otherwise set at 40) are not subject to any maximum as long as an annual maximum, to be agreed by negotiation, is observed. Sunday working is permitted as long as a day off or pay in lieu is provided in return. Nightwork by male workers is allowed for economic and technical reasons and nightwork by women and young people up to midnight is allowed without the need for special authorization. General conditions for these changes include the need for a collective agreement, a commitment by the employer to hire additional employees, and a principle that existing employees will not be compelled to work the new hours.

\section{Job security: employers' rights to hire and fire}

Job protection legislation is stronger in the systems of mainland Europe than it is in Britain, where there is a weaker form of unfair dismissal legislation, and in the US, where statutory controls are practically non-existent. Few of these systems have protections as strong as are provided in New Zealand however. The absence of legislation in Britain and the US is partially compensated for by collective bargaining and by the common law remedies for breach of contract; however, neither of these techniques provides an adequate basis for extending protection to lower-paid or under-represented groups of workers. As a result, job insecurity affects large numbers of full time, directly employed workers outside the unionized sectors. In the mainland European systems, by contrast, job insecurity is more closely related to employment status, in the sense that while full time, "permanent" workers enjoy substantial legal protections against dismissal, these protections are frequently waived in the case of "precarious" workers employed on temporary or part time contracts.

In the US, there is a clear divergence in both law and practice between the unionized and non-union sectors. Collective agreements usually contain arbitration clauses for dealing with individual discipline and dismissal which in practice set substantial limits on managerial prerogative. Decisions of arbitrators on compensation and reinstatement will be enforced by the courts. A smaller number of collective agreements also contain procedures for notifying unions of redundancies; these are similar to the general legislative requirements found in Western Europe. Federal legislation has only recently enacted a limited right to notification of plant closures for all employees. In the nonunion sector, by contrast, the rule until recently was that the employer could hire and fire at will. This rule has been only partially eroded at state level by a number of common law techniques. Most notably, state courts have given legal effect to promises of job security by interpreting them as terms of the employment contract. A number of public 
policy exceptions to employment at will have also been developed. Courts applying the common law will not order reinstatement, but in some states they have awarded large sums in compensation for breach of contract, representing lifetime earnings and damages for loss of reputation and distress. This has led some commentators to recommend the introduction of dismissal legislation which would at least place an upper limit on employers' liability for wrongful discharges (Weiler, 1989). However, these common law limitations on employment at will do not, as yet, amount to a systematic repudiation of the doctrine; in many cases they can be overcome by exemption clauses in contracts of employment and, in a large number of southern and western states, the rule continues to be applied without qualification.

The British system of unfair dismissal legislation preserves a considerable degree of discretion to the employer. Union approval for dismissals is not needed, and as long as certain minimum standards of procedural equity are observed, industrial tribunals are reluctant to overturn employers' decisions. Around 40,000 cases of dismissal go to industrial tribunals every year, of which only around a third result in a finding for the employee. In principle the first remedy for an unfair dismissal is re-employment, but tribunals hardly ever make this award (Dickens et al., 1985). Even if a tribunal orders reinstatement or re-engagement, the employer can refuse to obey on pain only of paying a higher sum in compensation. Compensation payments are limited by statute, and in recent years these limits have been held at the same level notwithstanding wage inflation, so eroding the value of these remedies to better paid employees.

Workers with less than 2 years' continuous service with their employer, and part time workers employed for under 16 hours each week ( 8 hours if they have 5 years' service), are excluded from protection against unfair dismissal and redundancy compensation. In addition, fixed-term contract workers are excluded if they agree in writing to waive their statutory rights (Deakin, 1986). These restrictions particularly affect low paid and short-term service workers who make up a disproportionate number of those who invoke the statutory unfair dismissal jurisdiction. In return, the employer is only required to grant a minimum term of employment of one year. A number of other changes have served to make unfair dismissal protection less effective. Tribunals have been empowered to order the payment of a pre-trial "deposit" by applicants whose claims appear dubious at a pre-hearing tribunal (Deakin, 1990a), and exceptions to the rules governing the dismissal and re-employment of pregnant employees have been made for small firms. Some employees may have common law rights which effectively substitute for statutory protection (Ewing and Grubb, 1987) but these tend to be public sector workers with long tenure, rather than workers employed on a low paid and short-term or part time basis.

The differences with continental European legislation are both procedural and substantive (Deakin, 1990b). The role of the labour court, for example, is more extensive in Italy and West Germany, where the court may in certain circumstances order the employment contract to be maintained notwithstanding the employer's decision to dismiss. The employer then has a choice of taking the worker back or continuing to pay wages regardless. In West Germany, the approval of the works council at plant level is usually required to ease the process of dismissal. In all the continental systems, the legal concept of "just cause" is more precise and less management-orientated than it is in British experience, with some countries (such as Italy) placing upon the employer the burden of proving just cause. Controls over redundancies in the form of pre-notification and consultation requirements are also a general feature of European labour legislation, in part as a result of the European Community Directives in this area (Deakin, 1990b, p.231). 


\section{The promotion of "atypical" employment}

The model of the "flexible firm" (Atkinson, 1985) suggested that firm-level segmentation of the labour force was increasingly likely to develop as a response to uncertainty, with firms splitting their labour force into a "core" of central staff, who would receive promises of permanent employment and career development, and a "periphery" of marginal employees - part time, temporary and sub-contract workers - who would act as a buffer between the core workforce and the labour market. The degree of legal change necessary to accommodate such a model of segmentation depends, however, on the level of legal job security enjoyed by the core employees. In the American system, the prevalence of employment at will outside the unionized sector makes it difficult to determine the extent of temporary and part time employment, but even allowing for this, it appears that there was only a small increase in "contingent" or marginal jobs in the 1970s and 1980s. Part time work grew from 15 to 18 percent of the employed labour force between 1968 and 1985; temporary work, although increasing, accounts for a very small proportion of those in employment (Rosenberg, 1989b).

Although the extent of non-standard working appears to be greater in Britain, there is no evidence of firms generally adopting a "core-periphery strategy" as a systematic aspect of manpower planning (Atkinson and Meager, 1986; Hakim, 1990; Marginson et al., 1988). Where firms have made greater use of flexible or atypical forms of employment, it has been largely in response to the uncertainties created by recession, rather than as a conscious strategy designed to replace more traditional patterns of labour hiring and deployment (Pollert, 1988).

Part time employment in Britain, defined as employment for 30 hours or less, currently accounts for around 23 percent of the employed labour force. In the early 1980s, around 1 million new part time jobs were created and an equivalent number of full time jobs were lost in the recession. Part time work is heavily dominated by married women (up to 85 percent) and is concentrated to a high degree in service sector occupations. Part time work has fallen in the manufacturing sector which itself is shrinking in relative terms (Rubery et al., 1990). Self-employment also grew in the 1980s from around 7 percent to 11 percent of the total working population (Creigh $e t a l$., 1987). Temporary employment accounts for a much smalier 6 percent of the employed labour force and there is some dispute as to whether it actually grew during the 1980 s (Meager, 1986; Casey, 1988). Both self-employment and temporary employment overlap significantly with part time work (Hakim, 1987).

The measures taken to encourage the growth of temporary and part time work include the changes to unfair dismissal law described above and changes to the system of social security taxation which have had the effect of encouraging reduction of hours below the thresholds for contribution (Deakin and Wilkinson, 1991). These thresholds are set at a relatively high level in comparison to other countries and are thought to exclude around 30 percent of all part time workers from the national insurance scheme (Schoer, 1987).

Whereas in Britain and the US changes to the law were not necessary in order to permit the growth of part time and temporary work, the traditional emphasis in the mainland European systems upon the contract of employment taking the form of a permanent hiring meant that new legislation was necessary to legitimate non-standard forms of work (Kravaritou-Manitakis, 1988; Deakin, 1990b). In the Federal Republic of Germany prior to the Employment Promotion Act of 1985, the Federal Labour Court had required employers to show a good reason for the employment of workers on a fixed-term contract. If no acceptable reason was available, the contract was assumed to be for an indefinite period and the employee received the full labour law protection of a regular worker. The 1985 Act removed these restrictions on fixed-term hirings in the case of new recruits and apprentices finishing their training, in each case providing for a maximum contract duration of 18 months after which each worker must be offered a permanent 
contract if they are to be retained. New firms, and firms employing fewer than 20 employees, may extend these contracts to 2 years (Däubler and Le Friant, 1986).

The other provisions of the Act were concerned with integrating atypical forms of work into at least a minimal level of labour law regulation, with the aim of making these forms of work more attractive for employees and providing "bridges" to full time work. A general principle requiring part timers to be treated equally with full timers, unless the differences could be objectively justified, was introduced. Employers are obliged to inform employees when jobs offering different working hours become available. Minimum regulations were also laid down for on-call contracts and job-sharing. Some provisions for derogation by collective agreement were also made. Initially the Act was envisaged as a temporary measure with a limited life of 5 years, but in 1990 the Federal Parliament voted to continue it in force for a further 5 year period.

In France, the legislation on atypical work of 1982 also introduced a general requirement of equal treatment for part time and temporary workers and also retained restrictions on the use of fixed-term contracts. These were allowed only to cover for the temporary absence of an employee; to provide for extra labour during a temporary increase in activity; to carry out a discrete task; to hire seasonal workers; and in the case of the hiring of unemployed persons. In these situations, the fixed-term contract would expire automatically without the need for a dismissal, but the worker would have the right to receive some severance pay.

In 1986, when a Conservative administration was in office, these regulations were replaced by a general provision permitting the use of a fixed term contract in any case involving the carrying out of a specific task. At the same time, the need for authorization from the labour inspectorate was abolished, the number of permitted renewals was raised from 1 to 2 , and the maximum duration of these contracts extended to 24 months. This law also authorized the formation of "intermittent" or irregular part time contracts and changed the law on firm-size thresholds so that part timers would only count pro-rata in the calculation of the number of the firms' employees for employment protection purposes, a measure designed to help small firms. With the return of a Socialist administration in 1988, these deregulating measures came under critical scrutiny, and in 1990 new legislation was passed once again tightening up the grounds permitting the formation of fixed-term contracts and extending the principle of equal treatment to cover fixed-term employees (Blaise, 1991).

Similar laws encouraging temporary work have been passed in Italy and Spain. Italian legislation of 1976 opened up the possibility of increased use of fixed-term hirings which had previously been restricted to seasonal working, temporary replacements and task contracts. The new law extended the range of cases to cover sectors subject to peaks of demand - tourism, commerce and private services - and delegated controls over the scale of fixed-term hirings to "most representative" unions at local level and to the labour inspectorate. In 1984, a law was passed to encourage regulation of part time work by collective agreements and to ensure that part time workers were counted as employees and that they enjoyed pro-rata social security rights. In Spain, the principal legal change concerns fixed-term contracts. A 1984 law created no fewer than 15 new forms of temporary work contract, based on varying justifications from the employers' point of view.

The relationship between these legal changes and the growth of non-full time jobs remains unclear, however. While atypical work has grown in all the European Community countries in the 1980 s, it is not possible to discern from this any general trend of demand-led flexibilization based on employers' needs for these particular forms of work. The numbers employed in atypical work vary considerably within the European systems (Marshall, 1989; Deakin, 1990b). The Netherlands has the highest proportion of employees in part time work at nearly 30 percent of the employed labour force. Part time work is only slightly less significant in Denmark, Sweden and Britain, whereas in France and West Germany it represents only between 10 and 15 percent of the employed labour 
force, and in Italy, Spain and Greece it accounts for less than 5 percent. Temporary work, which is less important than part time work in Britain and France, accounts for around a fifth of employment in Spain, Portugal and Greece.

In relation to Britain, Emerson (1988, p.801) has claimed that "part-time employment benefiting from these provisions has been the main growth element in aggregate employment in the United Kingdom in recent years", but this perspective fails to account for the steady growth in part time employment in Britain since the 1950s when the pressures of a tight labour market first led to an increase in female labour market participation rates (Hakim, 1990). There is no clear relationship between deregulation and subsequent growth. In France, a substantial growth in relative terms in the volume of part time work took place in the 1980s when employment rights were being extended to part time workers, while in the Federal Republic neither part time nor temporary work saw any very substantial increase in the share of total employment following the passage of the Employment Promotion Act. In Spain and Portugal, on the other hand, much of the recent growth in temporary work seems to be the result of the attempts of governments to promote this form of employment. In Spain, 90 to 95 percent of new hirings are in the form of temporary jobs and these now account for 30 percent of private sector employment (Recio, 1990).

Although the promotion of atypical work was undertaken with the aim of providing a route out of unemployment and into full time work, there is a danger that atypical jobs will become associated with segmentation of the labour market and reduced occupational mobility. In Britain, where there is no requirement of parity of treatment for part time and temporary workers, part time work tends to be associated with lower pay, reduced career prospects and higher levels of insecurity for employees (Rubery 1989). Even in systems where a formal commitment to equality is written into the law, discrimination continues to operate in terms of access to overtime pay, bonuses and seniority increments. In Germany, despite the formal commitment to equality, a number of thresholds continue to operate to exclude part timers from the scope of social legislation (Büchtemann and Quack, 1989). Even where part time workers do qualify for social protection, and have relatively stable employment relations with their employers, they tend to suffer from the twin disadvantages of limited career opportunities and reductions in long-term benefits such as retirement pensions.

The State's efforts to support part time and temporary jobs through subsidies to firms or in the form of reduced social protection create the problem of distortions to competition at international level, which has been raised through the European Commission's draft Directive on Atypical Employment Relationships (Deakin, 1990b). The same point can be made, however, within national systems; the selective removal of employment rights for part time and temporary workers runs the risk of creating a secondclass status of jobs within the labour market, undermining the "standard" pattern of full time work without providing any effective route out of unemployment. One result of such deregulation in the employment sphere is to shift the burden on to social security, principally in the form of social assistance (Thurman and Trah, 1990; Deakin and Wilkinson, 1991).

\section{The limits of deregulation?}

The wide variety of techniques and approaches used as a means of enhancing flexibility suggests that full-scale deregulation is only one of a range of options, and that it is from being the one most commonly used in practice. The apparently considerable legal flexibility of the British and American systems, when compared to the complex and multi-level forms of labour law regulation found in the continental systems, may, on further reflection, pose a barrier to the very kind of economic and social mobility which deregulation policies are meant to foster. Attempts to achieve greater flexibility by 
cutting employers' fixed labour costs and introducing greater variability in general wage levels may simply result in more insecure employment and under-investment in skills and education. Cuts in employment protection and the social wage in Britain and the US have increased social divisions, raising the prospect that the labour supply will be rendered less mobile and adaptable. A dualist labour law policy may simply result in the creation of new barriers to mobility between those in regular full time work and the rest. In these systems, deregulation has been an excuse for governments to avoid pursuing both effective training and mobility policies concerned with improving supply-side efficiency and a proper macroeconomic policy which would address the issues of continuing high levels of unemployment and the spread of poverty.

The preservation in most of the continental European systems of a basic floor of legal rights as a platform for bargaining over flexibility has presented a far more attractive prospect both for social cohesion and supply-side efficiency. In the final analysis, however, a strategy of defending the standard employment relationship can only work if a return to "full employment", as this was understood in the 1950 s and 1960 s, is possible. This is not possible, however, for a number of reasons which include the structural conditions of the developed economies, the impact of new technology, new patterns of labour supply and ecological constraints (Mückenberger, 1989). Under these circumstances, those systems retaining a strong level of employment protection face the dilemma that laws built up around the standard relationship will only ever provide for an increasingly small elite of workers. Parity of treatment is necessary if flexible work is to be a matter of choice rather than necessity, and this requires the continuing development of positive measures of state intervention to widen the principle of equality, and provide an infrastructure for labour force integration and occupational development.

\section{References}

ACAS (1987) Labour flexibility in Britain. London, Advisory, Conciliation and Arbitration Service. (Occasional Paper 41).

Addison, J. (1986) Job security in the United States: law, collective bargaining, policy and practice. British journal of industrial relations 24:381-418.

Ascher, K. (1987) The politics of privatisation: contracting out public services. London, Macmillan.

Atkinson, J. (1985) Flexibility, uncertainty and manpower management. Brighton, Institute of Manpower Studies.

Atleson, J. (1984) Values and assumptions in American labor law. Amherst, University of Massachusets Press.

Auerbach, S. (1991) Legislating for conflict. Oxford, Clarendon Press.

Blaise, H. (1991) Les contrats précaires après la loi du 12 juillet 1990. Droit social Janvier:11-15.

Blanpain, R. (ed.) (1988) Legal and contractual limitations on working time in the European Community. Luxembourg, European Foundation for the Improvement of Living and Working Conditions.

Bluestone, B. and Harrison, B. (1982) The deindustrialisation of America. New York, Basic Books.

Brown, W. and Walsh, J. (1990) Pay determination in Britain in the 1980s: the anatomy of decentralisation. Oxford review of economic policy 7:44-59. 
Büchtemann, C. and Quack, S. (1989) "Bridges" or "traps"? Non-standard employment in the Federal Republic of Germany. In G. and J. Rodgers (eds.) Precarious jobs in labour market regulation: the growth of atypical employment in Western Europe. Geneva, International Institute for Labour Studies.

Casey, B. (1988) Temporary employment in Britain. London, Policy Studies Institute.

Clark, G. (1989) Unions and communities under siege. Cambridge, Cambridge University Press.

Creigh, S., Roberts, C., Gorman, A. and Sawyer, P. (1987) Self-employment in Britain. Department of Employment gazette, January.

Däubler, W. and Le Friant, M. (1986) Un récent exemple de flexibilisation législative: la loi allemande pour la promotion de l'emploi du 26 avril 1985. Droit social SeptembreOctobre:715-720.

Deakin, S. (1986) Labour law and the developing employment relationship in the UK. Cambridge journal of economics. 10:225-246.

Deakin, S. (1990a) Equality under a market order: the Employment Act 1989. Industrial law journal 19:1-19.

Deakin, S. (1990b) The floor of rights in European labour law. New Zealand journal of industrial relations 15:219-240.

Deakin, S. and Wilkinson, F. (1991) Labour law, social security and economic inequality. Cambridge journal of economics 15:125-149.

Dickens, L., Jones, M., Weekes, B. and Hart, M. (1985) Dismissed: a study of unfair dismissal and the industrial tribunal system. Oxford, Blackwell.

Emerson, M. (1988) Regulation or deregulation of the labour market: policy regimes for the recruitment and dismissal of employees in industrialised countries. European economic review 32:775-817.

Erbes-Seguin, S. (1989) Flexibility and the relationship between the individual employment contract and collective labour law. International journal of the sociology of law 17:307-326.

Evans, S. (1990) Free labour markets and economic performance: evidence from the construction industry. Work, employment and society 4:239-242.

Ewing, K. and Grubb, A. (1987) The emergence of a new labour injunction. Industrial law journal 16:145-163.

Fredman, S. and Morris, G. (1989) The state as employer. Labour law in the public law services. London, Mansell.

Hakim, C. (1987) Trends in the flexible workforce. Department of Employment gazette, November.

Hakim, C. (1990) Workforce restructuring in Europe in the 1980s. International journal of comparative labour law and industrial relations 5:167-203.

Harrison, B. and Bluestone, B. (1988) The great U-turn: corporate structuring and the polarisation of America. New York, Basic Books.

Kravaritou-Manitakis, Y. (1988) New forms of work. Labour law and social security aspects in the European Community. Luxembourg, European Foundation for the Improvement of Living and Working Conditions. 
Lyon-Caen, A. and Mariucci, L. (1987) The state, legislative intervention and collective bargaining: a comparison of three national cases. International journal of comparative labour law and industrial relations 1:87-107.

Marginson, P., Edwards, P., Martin, R., Purcell, J. and Sisson, K. (1988) Beyond the workplace. Managing industrial relations in the multi-establishment enterprise. Oxford, Blackwell.

Marshall, A. (1989) The sequel of unemployment: the changing role of part time and temporary work in Western Europe. In G. and J. Rodgers (ed.) Precarious jobs in labour market regulation. Geneva, International Institute for Labour Studies.

Meager, N. (1986) Temporary work in Britain. Department of Employment gazette, January.

Metcalf, D. (1986) Labour market flexibility and jobs: a survey of evidence from OECD countries with special reference to Great Britain and Europe. London, Centre for Labour Economics, London School of Economics (Discussion paper No. 254).

Mückenberger, U. (1989) Non-standard forms of work and the role of changes in labour and social security regulation. International journal of the sociology of law 17:381-402.

Napier, B. (1989) Deregulation, flexibility and individual labour law in the United Kingdom. International journal of comparative labour law and industrial relations 4:206215 .

OECD (1986a) Labour market flexibility: a report by a high level group of experts to the Secretary-General. Paris.

OECD, (1986b) Flexibility in the labour market. Paris.

Pollert, A. (1988) The flexible firm: fixation or fact? Work, employment and society 2:281-316.

Recio, A. (1990) The quality of new jobs in Spain (1985-89). Paper presented to the Annual Conference of the International Working Party on Labour Market Segmentation, University of Trento.

Rogers, J. (1990) Divide and conquer: further "reflections on the distinctive character of American labor laws". Wisconsin law review :1-147.

Rosenberg, S. (1989a) The restructuring of the labor market, the labor force and the nature of employment relations in the United States in the 1980s. In S. Rosenberg (ed.) The State and the labor market. New York, Plenum.

Rosenberg, S. (1989b) Working time patterns in the United States: longer, shorter, and more flexible. Paper presented to the Conference on Labor Market Segmentation, University of Notre Dame.

Rosenberg, S. (1991) Deregulation, flexibility and the American worker: the legacy of governmental policies and managerial strategies in the 1980s. Paper presented to the Annual Conference of the International Working Party on Labour Market Segmentation, University of Bremen.

Rubery, J. (1989) Precarious forms of work in the United Kingdom. In G. and J. Rodgers (eds.) Precarious jobs in labour market regulation. Geneva, International Institute for Labour Studies.

Rubery, J., Horrell, S. and Burchell, B. (1990) Part time work and gender inequality in the labour market. Paper presented to the Annual Conference of the International Working Party on Labour Market Segmentation, University of Trento. 
Schoer, K. (1987) Part time employment: Britain and West Germany. Cambridge journal of economics 11:83-94.

Tarullo, D. (1989) Federalism issues in United States labour market policies and employment law. Paper presented to the Annual Conference of the International Working Party on Labour Market Segmentation, University of Nancy.

Thurman, J. and Trah, G. (1990) Part time work in international perspective. International labour review 129:23-40.

Tomlins, C. (1985) The state and the unions. Cambridge, Cambridge University Press.

TUC (1988) Review of working time in Britain and Western Europe. London.

UK Department of Employment (1985) Employment: the challenge for the nation. London, HMSO (Cmnd. 9474).

UK Department of Employment (1986) Building businesses ... not barriers. London, HMSO (Cmnd. 9794).

UK Department of Employment (1988) Employment for the 1990s. London, HMSO (Cmnd. 540).

Wedderburn, Lord and Sciarra, S. (1988) Collective bargaining as agreement and as law: neo-contractualist and neo-corporative tendencies of our age. In A. Pizzorusso (ed.) Law in the making. Berlin, Springer-Verlag.

Wedderburn, Lord (1986) The worker and the law. Harmondsworth, Penguin.

Wedderburn, Lord (1990) The social charter, European company and employment rights: an outline agenda. London, Institute of Employment Rights.

Weiler, P. (1989) Governing the workplace. Cambridge, Harvard University Press. 